\title{
Analisis Potensi Ekonomi Pada Sektor Dan Subsektor Pertanian, Kehutanan Dan Perikanan Di Kabupaten Tambrauw Tahun 2013 -2017
}

\author{
Sisilia Maria Parinusa ${ }^{1}$ \\ ${ }^{1}$ Dosen Jurusan Ekonomi Pembangunan, Universitas Papua
}

Received: Juli 2019; Accepted: Agustus 2019; Published: September 2019

\begin{abstract}
Abstrak
Sektor pertanian, kehutanan dan perikanan memiliki peranan penting dalam mengerrakkan pertumbuhan ekonomi di Kabupaten Tambrauw. Hal ini dapat terlihat dari nilai kontribusi sektor ini terhadap nilai tambah PDRB lebih dari 33 persen. Tujuan dari penelitian ini adalah untuk mengidentifikasi dan menganalisa subsector pertanian, kehutanan dan perikanan yang memiliki nilai potensial. Dengan menggukan metode Location Quotient $(L Q)$ dan analisis Shift Share serta didukung oleh data runtut waktu selama 5 tahun berturut - turut untuk wilayah studi dan wilayah acuan maka subsektor yang potensial dapat ditentukan. Hasil penelitian mengungkapkan bahwa golongan tanaman pangan, golongan hortikultura dan subsektor kehutanan dan penebangan kayu merupakan sektor unggulan yang mendorong pendapatan wilayah Kabupaten Tambrauw dikarenakan nilai LQ untuk dua golongan tanaman dan 1 subsektor ini nilainya lebih dari 1 dan memiliki nilai keunggulan kompetitif yang positif.
\end{abstract}

Kata kunci: Potensi ekonomi, location quotient, shift share

\begin{abstract}
Agriculture, forestry and fishery sector has an important role in generating the economic growth in Tambrauw Regency. It can be seen from the amount of its contribution to the gross value added which is more that 33 percent. The aim of this study is to identify and analyse the potential subsector of agriculture, forestry and fisheries sector in Tambrauw Regency. By using Location Quotient (LQ) Method and Shift Share analysis and supported by a time series data of GDP growth between the study area and reference area in the recent five years the potential subsectors can be determined. The research result reveals that food plant, horticulture group and forestry and logging subsector are the potential subsectors to promote the regional income due to their location quotient greater than 1 and have positive competitive advantage values.
\end{abstract}

Keywords: Economic potency, location quotient, shift share

How to Cite: Parinusa, S.M. (2019). Analisis Potensi Ekonomi Pada Sektor Dan Subsektor Pertanian, Kehutanan Dan Perikanan Di Kabupaten Tambrauw Tahun 2013 -2017. JFRES: Journal of Fiscal and Regional Economy Studies, 2 (2), 17 - 25.

\footnotetext{
Corresponding author:

E-mail: sisilia.parinussa@gmail.com
} 


\section{PENDAHULUAN}

Pembangunan ekonomi daerah adalah suatu proses dimana pemerintah dan masyarakatnya mengelola sumber daya - sumber daya yang ada dan membentuk suatu pola kemitraan antara pemerintah daerah dengan sektor swasta untuk menciptakan suatu lapangan kerja baru dan merangsang perkembangan kegiatan ekonomi dalam wilayah tersebut. Perbedaan kondisi daerah membawa implikasi bahwa corak pembangunan yang diterapkan berbeda pula. Peniruan mentah - mentah pola kebijaksanaan yang perah diterapkan dan berhasil pada suatu daerah, belum tentu memberikan manfaat yang sama bagi daerah lainnya (Sun'an dan Senuk, 2015).

Perbedaan dalam potensi, kondisi dan karakteristik yang dimiliki oleh masing - masing wilayah akan memperlihatkan perbedaan dalam kemampuan berkembangnya suatu wilayah, dengan demikian strategi pembangunan yang dilaksanakan akan berbeda pula. Pertukaran berbagai komoditas atau barang antar wilayah memperlihatkan terjadinya keterkaitan atau hubungan antar wilayah yang berbeda - beda potensinya. Pertukaran atau perdagangan antar wilayah yang saling membutuhkan dilakukan berdasarkan azas keunggulan komparatif (comparative advantage). Karena memiliki potensi sumberdaya alam yang besar, maka wilayah yang bersangkutan mampu berproduksi dengan tingkat biaya produksi relatif terendah. Tiap - tiap wilayah pertumbuhan memiliki keunggulan relatifnya masing - masing, sehingga menumbuhkan kegiatan yang saling membutuhkan dan saling ketergantungan antar wilayah. Kecenderungan saling membutuhkan dan saling ketergantungan mendorong dilakukannya pembagan kerja antar wilayah atau spesialisasi antar wilayah.

Kabupaten Tambrauw adalah salah satu kabupaten baru di Papua Barat yang beribukota di Distrik Fef. Dasar hukum pembentukan kabupaten ini adalah Undang - Undang Republik Indonesia nomor 56 tahun 2008. Menurut BPS Kabupaten Sorong (2017), Pada tahun 2017 kategori lapangan usaha pertanian, kehutanan dan perikanan memberikan kontribusi terhadap PDRB atas dasar harga berlaku sebesar 64,596 miliar rupiah atau mencapai 33,35 persen.

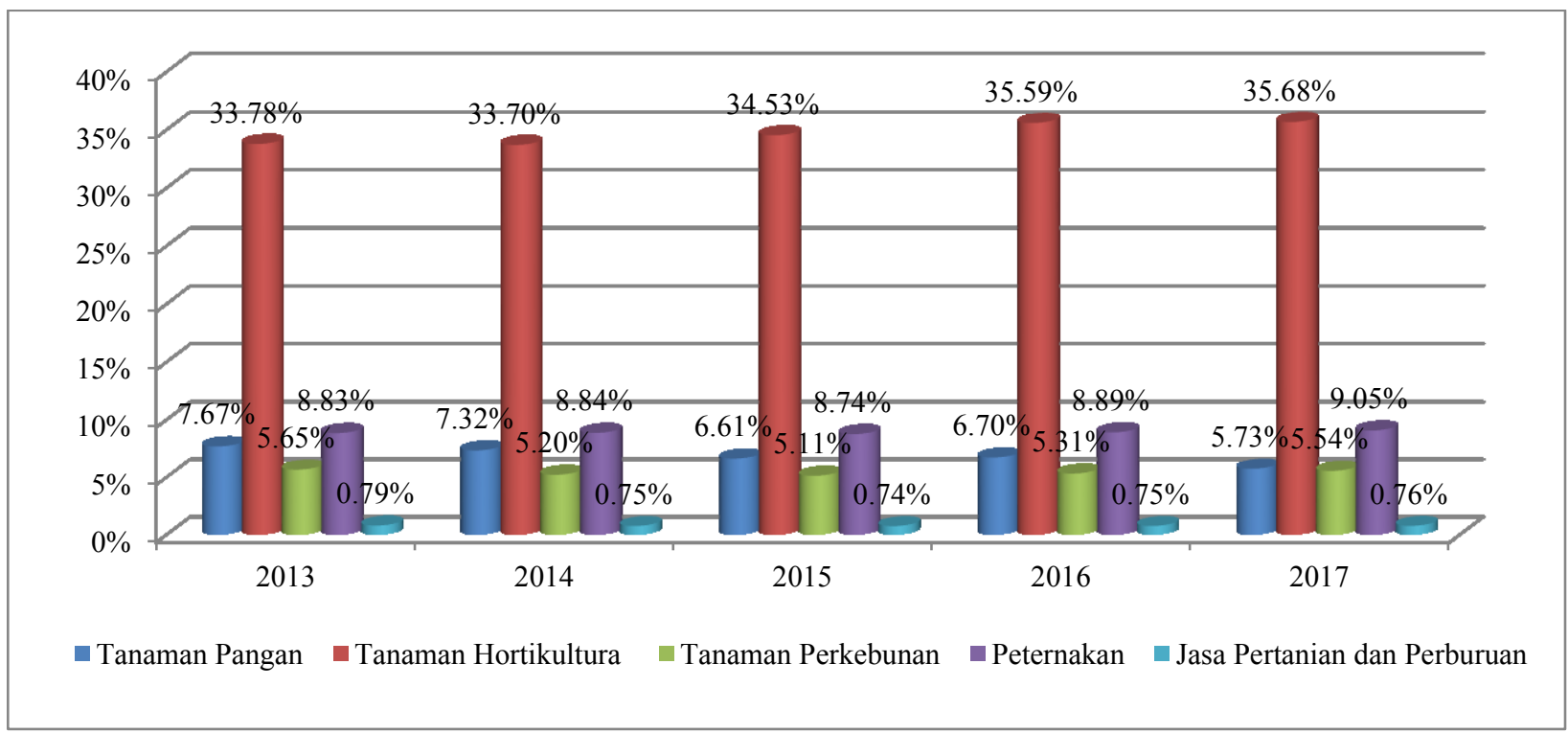

\section{Sumber: BPS, data diolah 2019.}

Gambar 1. Kontribusi Subsektor Pertanian, Peternakan, Perburuan dan Jasa Pertanian

Subkategori pertanian, peternakan, perburuan dan jasa pertanian merupakan penyumbang terbesar dalam menciptakan nilai tambah. Kontribusi kategori pertanian, kehutanan dan perikanan mencapai 56,77 persen terhadap
PDRB sektor pertanian, kehutanan dan perikanan Kabupaten Tambrauw. Dengan melihat besarnya peranan sektor pertanian, kehutanan dan perikanan bagi pendapatan wilayah maka penelitian ini bertujuan untuk 
mengidentifikasi dan menentukan subsektor apa saja yang menjadi subsektor unggulan di Kabupaten Tambrauw dan memiliki daya saing yang tinggi sehingga dapat menggerakkan pertumbuhan ekonomi di wilayah ini.

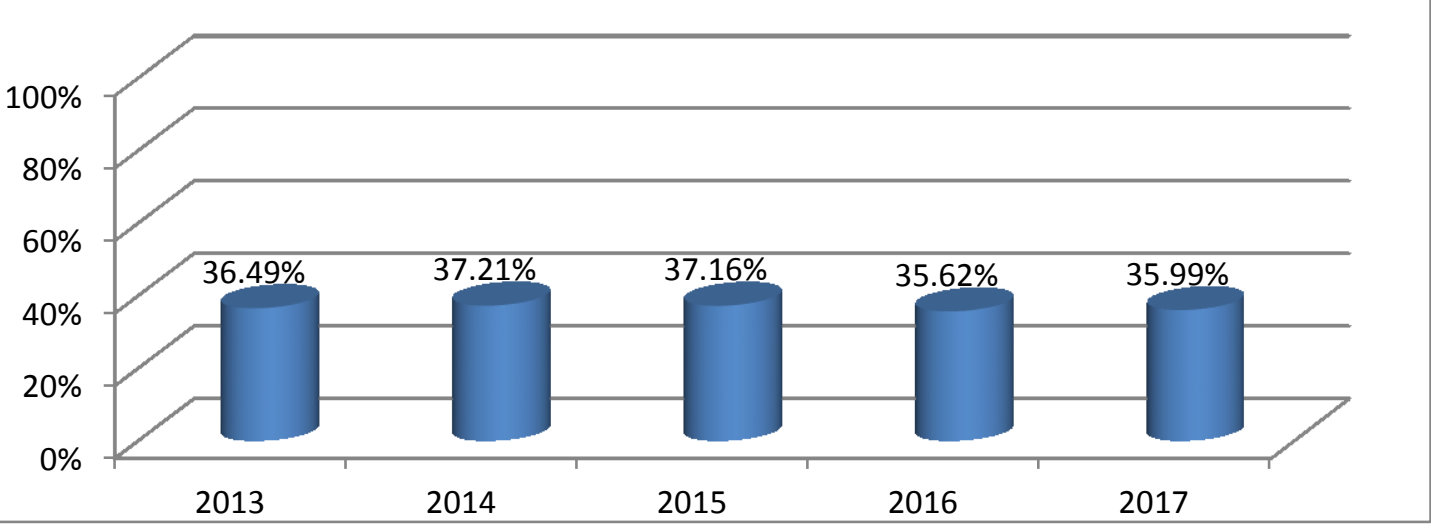

Sumber: BPS, data diolah 2019.

Gambar 2. Kontribusi Subsektor Kehutanan dan Penebangan Kayu

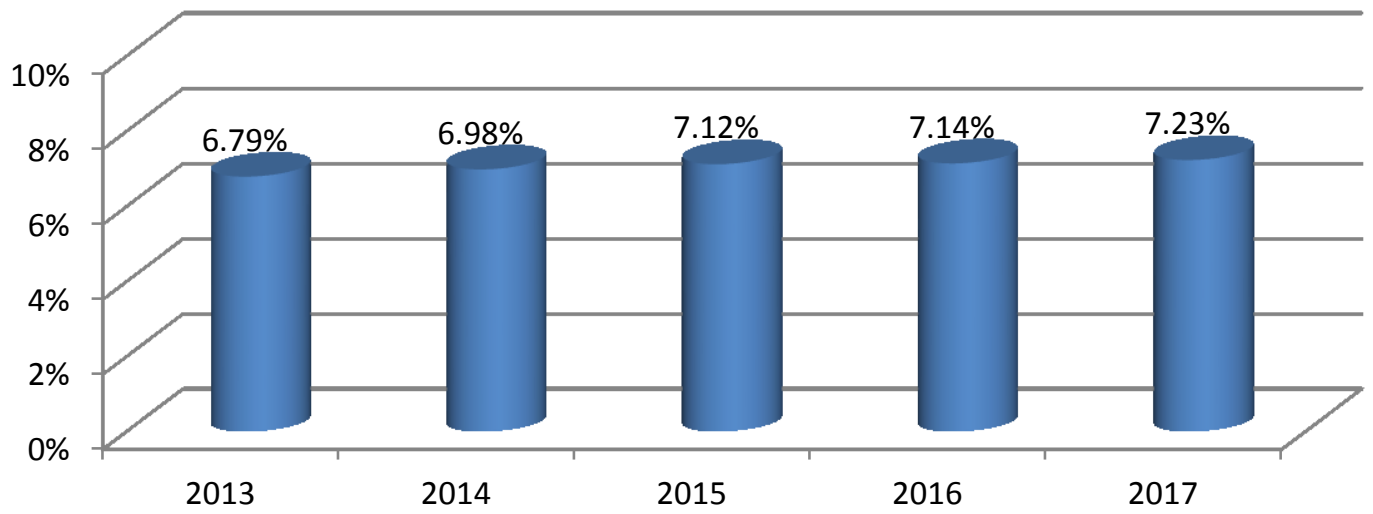

\section{Sumber: BPS, data diolah 2019.}

Gambar 3. Kontribusi Subsektor Perikanan

Beberapa penelitian empiris telah dilakukan untuk melihat potensi ekonomi pada sektor dan subsektor pertanian, kehutanan dan perikanan pada suatu wilayah antara lain studi yang dilakukan Rizani Ahmad (2017) yang mengkaji potensi ekonomi di sektor dan subsektor pertanian, kehutanan dan perikanan Kabupaten Jember dengan metode analisis LQ, shift share dan model rasio pertumbuhan (MRP). Hasil penelitiannya mengungkapkan bahwa di Kabupaten Jember yang menjadi sektor dan subsektor unggulan ialah sektor pertanian, peternakan, perburuan dan jasa pertanian serta subsektor tanaman perkebunan karena nilai LQ $>1$ dan berdasarkan hasil analisis shift share peningkatan kinerja perekonomian Kabupaten Jember dapat dilihat dari sektor dan subsektor pertanian, kehutanan dan perikanan yang bernilai positif. Berdasarkan Kemudian dalam studi yang dilakukan oleh Steeva Tumangkeng (2018) tentang analisis potensi ekonomi di sektor dan subsektor pertanian, kehutanan dan perikanan Kota Tomohon menemukan bahwa yang menjadi sektor unggulan adalah subsektor pertanian, peternakan, perburuan dan jasa pertanian, subsektor tanaman hortikultura, subsektor peternakan, dan subsektor jasa pertanian dan perburuan. Sedangkan berdasarkan hasil analisis shift share, yang menjadi penyumbang terbesar bagi pembentukan PDRB Kota Tomohon adalah subsektor pertanian, peternakan, perburuan dan jasa pertanian, subsektor perkebunan, subsektor peternakan, subsektor hortikultura, dan subsektor tanaman pangan. Selanjutnya Susi Roria Sari (2018) dalam penelitiannya mengungkapkan bahwa 
berdasarkan hasil analisis overlay antara Location Quotient (LQ), Dinamic Location Quotient (DLQ), serta analisis shift share subsektor tanaman pangan, subsektor tanaman perkebunan, jasa pertanian dan perikanan adalah sektor unggulan di Kabupaten Kaur dan Provinsi Bengkulu. Walaupun beberapa penelitian telah dilakukan belum nampak penelitian yang membahas keunggulan kompetitif sektor dan subsektor pertanian, kehutanan dan perikanan sehingga hal yang membedakan penelitian terdahulu dengan penelitian yang dilakukan penulis adalah selain menentukan sektor dan subsektor apa saja yang menjadi sektor unggulan di bawah kategori lapangan usaha pertanian, kehutanan dan perikanan, penelitian ini juga ingin melihat subsektor apa saja yang memiliki keunggulan kompetitif atau berdaya saing tinggi bukan saja untuk perdagangan lokal di wilayah Kabupaten melainkan juga di tingkat Provinsi Papua Barat. Selain itu, yang membedakan penelitian ini dengan penelitian terdahulu adalah metode analisis data yang digunakan yaitu mengkombinasikan hasil perhitungan pada analisis LQ dan analisis shift share untuk menentukan sektor yang potensial di wilayah Kabupaten Tambrauw.

Adapun teori yang digunakan untuk membangun penelitian ini adalah teori pertumbuhan ekonomi wilayah yaitu teori basis ekonomi (Economic Base Theory) dan teori sektor. Teori basis ekonomi membagi negara - negara (wilayah wilayah) dalam dua kelompok yaitu 1) negara (wilayah) yang mengekspor atau menjual dan negara (wilayah) yang membeli. Teori basis ekonomi menggunakan asumsi bahwa ekspor adalah satu - satunya faktor yang bersifat eksogen (independen) terhadap pengeluaran, artinya semua unsur pengeluaran lain adalah terikat (dependen) terhadap pembangunan. Hanya ekspor yang dapat mendorong peningkatan pendapatan daerah, sektor- sektor lain akan meningkat apabila pendapatan daerah secara keseluruhan meningkat. Asumsi lainnya, teori basis ekonomi membagi kegiatan sektor menjadi dua, yaitu kegiatan basis (basic activities) dan kegiatan non basis (nonbasic activities).

Selanjutnya, teori sektor mengemukakan pertumbuhan ekonomi wilayah melalui perubahan atau konstribusi antar sektor. Hipotesis Clark - Fisher mengemukakan bahwa suatu peningkatan dalam pendapatan per kapita akan diikuti oleh suatu penurunan dalam proporsi sumberdaya yang dimanfaatkan dala sektor primer (pertanian) dan suatu peningkatan dalam sektor sekunder (industri manufaktur) dan kemudian sektor - sektor tersier (jasa). Dalam perekonomian yang maju terjadi penurunan peranan sektor pertanian, peningkatan peranan sektor industri dan sektor jasa. Penurunan peranan dan dan peningkatan peranan sektor sektor dinyatakan dalam kontribusinya terhadap Produk Domestik Regional Bruto (PDRB). Kontribusi dimaksudkan membandingkan nilai produksi suatu sektor terhadap nilai total PDRB atau seluruh sektor. Perbandingan adalah suatu rasio. Rasio menunjukkan nilai relatif.

\section{METODE PENELITIAN}

\section{a. Variabel Penelitian dan Definisi Operasional}

1) Produk Domestik Regional Bruto (PDRB) adalah nilai tambah bruto seluruh barang dan jasa yang tercipta atau dihasilkan di wilayah domestik suatu negara yang timbul akibat berbagai berbagai aktivitas ekonomi dalam suatu periode tertentu, tanpa memperhatikan apakah faktor produksi yang digunakan merupakan milik residen atau non residen.

2) PDRB atas dasar harga berlaku adalah PDRB yang disusun berdasarkan harga yang berlaku pada periode perhitungan dan bertujuan untuk melihat struktur perekonomian.

3) PDRB atas dasar harga kosntan adalah PDRB yang disusun berdasarkan harga pada tahun dasar dan bertujuan untuk mengukur pertumbuhan ekonomi.

\section{b. Metode Pengumpulan Data}

Metode pengumpulan data yang digunakan dalam penelitian adalah metode studi kepustakaan. Metode ini merupakan cara pengumpulan data dengan mengadakan penelitian kepustakaan yaitu dengan mempelajari literatur yang berhubungan dengan penelitian ini yaitu bahan - bahan publikasi yang diterbitkan oleh Badan Pusat Statistik (BPS) Provinsi Papua Barat dan BPS Kabupaten Sorong, jurnal penelitian dan buku - buku ekonomi wilayah.

\section{c. Jenis dan Sumber Data}

\section{1) Jenis Data}

Data yang digunakan dalam penelitian adalah data sekunder yaitu jenis data time series dengan periode pengamatan selama 5 tahun yaitu tahun 2013 - 2017. Data yang digunakan antara lain 
Produk Domestik Regional Bruto atas dasar harga konstan tahun 2010 sub kategori lapangan usaha Pertanian, Perikanan dan Kehutanan Provinsi Papua Barat dan Kabupaten Tambrauw periode 2013 - 2017 serta Produk Domestik Regional Bruto atas dasar harga berlaku subkategori lapangan usaha Pertanian, Perikanan dan Kehutanan Provinsi Papua Barat dan Kabupaten Tambrauw periode 2013 - 2017. Data ini akan digunakan untuk menghitung analisis Location Quotient untuk penentuan sektor basis serta untuk menghitung analisis shift share untuk melihat struktur ekonomi Kabupaten Tambrauw.

\section{2) Sumber data}

Data yang digunakan dalam penelitian ini adalah data sekunder yang berasal dari bahan - bahan publikasi yang dikeluarkan oleh instansi pemerintah terkait antara lain Badan Pusat Statistik Kabupaten Sorong dan Badan Pusat Statistik Provinsi Papua Barat.

\section{3) Metode Analisis}

Penelitian ini menggunakan alat analisis Location Quotient (LQ) dan analisis Shift Share. a. Metode Location Quotient (LQ)

Metode LQ membandingkan porsi lapangan kerja / nilai tambah untuk suatu sektor tertentu di suatu wilayah dibandingkan dengan porsi lapangan kerja / nilai tambah untuk sektor yang sama secara nasional. Istilah nasional ditujukan untuk wilayah yang lebih tinggi jenjangnya. Dalam hal ini wilayah analisis adalah wilayah Kabupaten Tambrauw maka istilah nasional digunakan untuk wilayah Provinsi Papua Barat. Adapun rumus untuk menghitung LQ adalah sebagai berikut:

$L Q=\frac{\text { PDRBi/PDRB Tot Kabupaten }}{\text { PDRBi/PDRB Tot Provinsi }}$

dimana :

$\mathrm{LQ}=$ indeks Location Quotient

PDRBi $=$ PDRB sektor i Kabupaten Tambrauw dalam juta rupiah

PDRB Total Kabupaten = PDRB total Kabupaten Tambrauw dalam juta rupiah

PDRBi $=$ PDRB sektor i di Provinsi Papua Barat dalam miliar rupiah

PDRB Total Provinsi $=$ PDRB total Provinsi Papua Barat dalam miliar rupiah
Berdasarkan persamaan (1) di atas, maka terdapat tiga kemungkinan nilai LQ yang dapat diperoleh yaitu:

1. Nilai $\mathrm{LQ}=1$, artinya bahwa tingkat spesialisasi atau basis sektor i di wilayah Kabupaten Tambrauw adalah sama dengan sektor yang sama dalam perekonomian wilayah Provinsi Papua Barat.

2. Nilai LQ $>1$, artinya bahwa tingkat spesialisasi atau basis sektor i di wilayah Kabupaten Tambrauw lebih besar dibandingkan dengan sektor yang sama dalam perekonomian Provinsi Papua Barat.

3. Nilai LQ $<1$, artinya bahwa tingkat spesialisasi atau basis sektor $\mathrm{i}$ di wilayah Kabupaten Tambrauw lebih kecil dibandingkan dengan sektor yang sama dalam Perekonomian Provinsi Papua Barat.

Apabila nilai $\mathrm{LQ}>1$, maka dapat disimpulkan bahwa sektor tersebut merupakan sektor basis dan potensial untuk dikembangkan sebagai penggerak perekonomian Kabupaten Tambrauw. Sebaliknya, apabilai nilai LQ $<1$, maka sektor tersebut bukan merupakan sektor basisdan kurang potensial untuk dikembangkan sebagai penggerak perekonomian Kabupaten Tambrauw.

\section{b. Analisis Shift Share}

Analisis shift share digunakan untuk mengetahui perubahan dan pergeseran sektor pada perekonomian wilayah Kabupaten Tambrauw. Hasil analisis shift share akan menggambarkan kinerja sektor - sektor dalam PDRB Kabupaten Tambrauw dibandingkan dengan Provinsi Papua Barat. Selanjutnya, akan dilakukan analisis terhadap peyimpangan yang terjadi sebagai hasil perbandingan tersebut. Apabila penyimpangan yang terjadi bernilai positif maka dapat dikatakan bahwa suatu sektor dalam PDRB Kabupaten Tambrauw memiliki keunggulan kompetitif, sebaliknya apabila penyimpangan yang terjadi bernilai negatif maka sektor tersebut dalam PDRB Kabupaten Tambrauw tidak memiliki keunggulan kompetitif.

Menurut Arsyad (2005), teknik analisis shift share membagi perubahan pertumbuhan (Dij) menjadi tiga komponen, yaitu:

1. Pengaruh pertumbuhan ekonomi di atasnya (Nij), yang diukur dengan cara menganalisis perubahan pengerjaan agregat secara sektoral dibandingkan dengan perubahan pada sektor 
yang sama di perekonomian yang dijadikan acuan.

2. Pengaruh pergeseran proporsional atau bauran industri (Mij), yang mengukur perubahan pertumbuhan atau penurunan pada daerah studi dibandingkan dengan perekonomian yang lebih besar yang dijadikan acuan. Dimana melalui pengukuran ini dimungkinkan untuk mengetahui apakah perekeonomian daerah studi terkonsentrasi pada industri - industri yang tumbuh lebih cepat ketimbang perekonomian yang dijadikan acuan.

3. Pengaruh pergeseran diferensial atau keunggulan kompetitif (Cij), yang menentukan seberapa jauh daya saing industri daerah (lokal) dengan perekonomian yang dijadikan acuan, dimana jika pergeseran diferensial dari suatu sektor adalah positif, maka sektor tersebut lebih tinggi daya saingnya ketimbang sektor yang sama pada perekonomian yang dijadikan acuan.

Menurut Prasetyo Soepomo dalam Arif Kurniawan (2013), bentuk umum analisis shift share dan komponen - komponennya adalah:

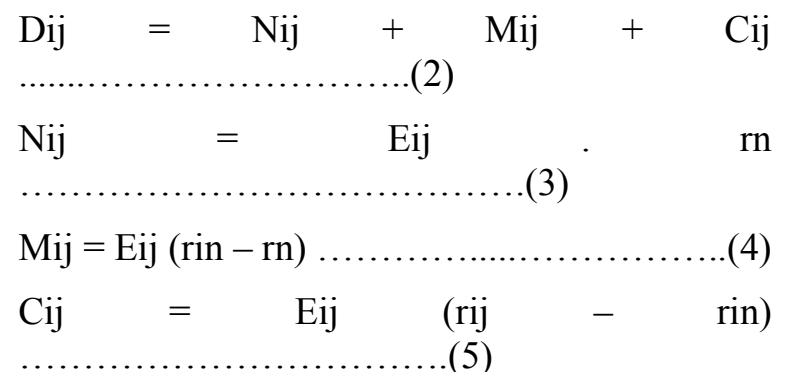

dimana:

$\mathrm{i}=$ sektor - sektor ekonomi yang dimiliki

$\mathrm{j}=$ variabel wilayah yang diteliti (Kabupaten Tambrauw)

Dij = perubahan sektor i di daerah $\mathrm{j}$ (Kabupaten Tambrauw)

$\mathrm{Nij}=$ pertumbuhan sektor $\mathrm{i}$ di daerah $\mathrm{j}$ (Kabupaten Tambrauw)

Mij = bauran industri sektor $\mathrm{i}$ di daerah $\mathrm{j}$ (Kabupaten Tambrauw)

$\mathrm{Cij}=$ keunggulan kompetitif sektor $\mathrm{i}$ di daeraj $\mathrm{j}$ (Kabupaten Tambrauw)

Eij $=$ PDRB sektor $\mathrm{i}$ di daerah $\mathrm{j}$ (Kabupaten Tambrauw)

rij = laju pertumbuhan sektor $\mathrm{i}$ di daerah $\mathrm{j}$ (Kabupaten Tambrauw) rin $=$ laju pertumbuhan sektor $\mathrm{i}$ di daerah $\mathrm{n}$ (Provinsi Papua Barat)

$\mathrm{rn}=$ laju pertumbuhan PDRB di daerah $\mathrm{n}$ (Provinsi Papua Barat)

Masing - masing laju pertumbuhan didefinisikan sebagai berikut:

1. Mengukur laju pertumbuhan sektor i di wilayah $\mathrm{j}$, rumusnya: $\mathrm{rij}=\left(\mathrm{e}^{*} \mathrm{ij}-\mathrm{eij}\right) / \mathrm{eij}$

2. Mengukur laju pertumbuhan sektor i perekonomian nasional, rumusnya: $\operatorname{rin}=\left(\mathrm{e}^{*}\right.$ in ein)/ein

3. Mengukur laju pertumbuhan nasional, rumusnya: $r n=\left(e^{*} n-e n\right) /$ en

dimana:

$\mathrm{e}^{*}$ in $=$ PDRB sektor i di tingkat nasional pada tahun terakhir analisis

ein $=$ PDRB sektor i di tingkat nasional pada suatu tahun dasar tertentu

$\mathrm{e}^{*} \mathrm{ij}=$ PDRB sektor $\mathrm{i}$ di wilayah $\mathrm{j}$ pada tahun terakhir analisis

eij $=$ PDRB sektor I di wilayah $\mathrm{j}$ pada suatu tahun dasar tertentu

$\mathrm{e}^{*} \mathrm{n}=$ PDRB nasional pada tahun terakhir analisis

en $=$ PDRB nasional pada suatu tahun dasar tertentu

\section{HASIL DAN PEMBAHASAN}

\section{a. Analisis Location Quotient (LQ)}

Location quotient (kuosien lokasi) atau biasa disebut LQ adalah suatu perbandingan tentang besarnya peranan suatu sektor atau industri di suatu daerah terhadap besarnya peranan sektor atau industri tersebut secara nasional. Ada banyak variabel yang bisa diperbandingkan, tetapi yang umum adalah nilai tambah (tingkat pendapatan). Istilah wilayah nasional dapat diartikan untuk wilayah induk atau wilayah atasan. Pada penelitian ini tingkat pendapatan wilayah Kabupaten Tambrauw dibandingkan dengan tingkat pendapatan wilayah atasannya yaitu Provinsi Papua Barat. Apabila nilai LQ $>1$ menunjukkan bahwa peranan subsektor tersebut lebih dominan di tingkat kabupaten dibandingkan dengan sektor yang sama di tingkat provinsi dan merupakan petunjuk bahwa kabupaten surplus akan produk subsektor tersebut. Sebaliknya, apabila nilai LQ $<1$ maka 
berarti bahwa peranan sektor tersebut lebih kecil di kabupaten dibandingkan dengan peranannya di tingkat provinsi.

Tabel 1 menjelaskan bahwa terdapat lima subkategori lapangan usaha yang menjadi sektor basis di bawah kategori lapangan usaha Pertanian, Kehutanan dan Perikanan antara lain subkategori tanaman pangan, subkategori tanaman hortikultura, subkategori peternakan, subkategori jasa pertanian dan perburuan serta subkategori kehutanan dan penebangan kayu. Sedangkan hanya terdapat dua subkategori lapangan usaha yang bukan menjadi subsektor basis yaitu golongan tanaman perkebunan yang berada di bawah subsektor pertanian, peternakan, perburuan dan jasa pertanian serta subsektor perikanan dengan nilai LQ masing masing 0,610 dan 0,135 .

Tabel 1. Analisis Sektor Potensial Sub Kategori Pertanian, Kehutanan dan Perikanan Kabupaten Tambrauw Tahun $2013-2017$

\begin{tabular}{|c|c|c|c|c|c|c|c|}
\hline \multirow{2}{*}{ Sub Kategori Lapangan Usaha } & \multicolumn{5}{|c|}{ LQ } & \multirow{2}{*}{$\begin{array}{l}\text { Rata- } \\
\text { Rata }\end{array}$} & \multirow{2}{*}{ Keterangan } \\
\hline & 2013 & 2014 & 2015 & 2016 & 2017 & & \\
\hline \multicolumn{8}{|c|}{ 1. Pertanian, Peternakan, Perburuan dan Jasa Pertanian } \\
\hline 1.1 Tanaman Pangan & 2,287 & 2,338 & 2,118 & 2,429 & 2,464 & 2,327 & Basis \\
\hline 1.2 Tanaman Hortikultura & 4,697 & 4,698 & 4,723 & 4,932 & 5,149 & 4,840 & Basis \\
\hline 1.3 Tanaman Perkebunan & 0,649 & 0,608 & 0,583 & 0,591 & 0,618 & 0,610 & Non Basis \\
\hline 1.4 Peternakan & 1,240 & 1,231 & 1,187 & 1,168 & 1,187 & 1,203 & Basis \\
\hline 1.5 Jasa Pertanian dan Perburuan & 1,219 & 1,203 & 1,173 & 1,169 & 1,202 & 1,193 & Basis \\
\hline 2. Kehutanan dan Penebangan Kayu & 1,547 & 1,636 & 1,716 & 1,781 & 1,837 & 1,703 & Basis \\
\hline 3. Perikanan & 0,317 & 0,135 & 0,136 & 0,133 & 0,134 & 0,135 & Non Basis \\
\hline
\end{tabular}

Sumber: Data diolah, 2019.

Selanjutnya, nilai LQ dapat digunakan sebagai petunjuk adanya keunggulan komparatif bagi sektor - sektor yang telah lama berkembang, sedangkan bagi sektor yang baru atau sedang tumbuh apalagi yang selama ini belum pernah ada, LQ tidak dapat digunakan karena produk totalnya belum menggambarkan kapasitas riil daerah tersebut. Berdasarkan hasil perhitungan pada tabel 1 di atas memperlihatkan bahwa wilayah Kabupaten Tambrauw memiliki keunggulan komparatif untuk produk - produk yang berasal dari golongan tanaman pangan, golongan tanaman hortikultura, golongan peternakan, golongan jasa pertanian dan perburuan serta produk - produk yang berasal dari subsektor kehutanan dan penebangan kayu. Sehingga adalah lebih tepat untuk melihat secara langsung apakah komoditi itu memiliki prospek untuk diekspor atau tidak, dengan catatan produk tersebut tidak diberikan subsidi atau bantuan khusus oleh daerah yang bersangkutan melebihi yang diberikan daerah - daerah lainnya.

Tabel 2. Hasil Perhitungan Nilai Shift Share Sub Sektor Pertanian, Kehutanan dan Perikanan Kabupaten Tambrauw Tahun 2013 - 2017 (Juta Rupiah)

\begin{tabular}{|c|c|c|c|c|}
\hline \multirow[b]{2}{*}{$\begin{array}{l}\text { Sub Sektor Pertanian, Kehutanan } \\
\text { dan Perikanan }\end{array}$} & \multicolumn{3}{|c|}{ Komponen } & \multirow{2}{*}{$\begin{array}{c}\text { Dampak } \\
\text { Nyata } \\
\text { Pertumbuhan } \\
\text { (Dij) }\end{array}$} \\
\hline & $\begin{array}{c}\text { Pertumbuhan } \\
\text { Nasional } \\
\text { (Nij) }\end{array}$ & $\begin{array}{c}\text { Bauran } \\
\text { Industri (Mij) }\end{array}$ & $\begin{array}{c}\text { Keunggulan } \\
\text { Kompetitif } \\
\text { (Cij) }\end{array}$ & \\
\hline $\begin{array}{l}\text { 1. Pertanian, Peternakan, Perburuan } \\
\text { dan Jasa Pertanian }\end{array}$ & 3823.093756 & 0 & -1174.833416 & 2648.26 \\
\hline a. Tanaman Pangan & 516.9804145 & -1177.530722 & 84.36951764 & -576.181 \\
\hline b. Tanaman Hortikultura & 2276.870717 & -616.3191336 & 814.1994761 & 2474.751 \\
\hline c. Tanaman Perkebunan & 380.8265114 & 87.18602748 & -259.3954088 & 208.6171 \\
\hline d. Peternakan & 595.1678045 & 313.2706339 & -394.3179883 & 514.1205 \\
\hline e. Jasa Pertanian dan Perburuan & 53.24830867 & -9.646269576 & -21.44876909 & 22.15327 \\
\hline 2. Kehutanan dan Penebangan Kayu & 2459.532637 & -3096.133193 & 2084.922385 & 1448.322 \\
\hline 3. Perikanan & 457.6658428 & 311.4822059 & -243.8294387 & 525.3186 \\
\hline Jumlah & 10563.38599 & -4187.690451 & 889.6663578 & 7265.362 \\
\hline
\end{tabular}

Sumber: Data diolah, 2019. 


\section{b. Analisis Shift Share}

Pada tabel 2 terlihat bahwa perekonomian Kabupaten Tambrauw untuk sektor dan subsektor pertanian, kehutanan dan perikanan selama periode 2013 - 2017 mengalami peningkatan sebesar Rp7265,362 juta rupiah atau sebesar $\mathrm{Rp}$ 7.265.362.000. Peningkatan kinerja ekonomi Kabupaten Tambrauw tersebut dapat dilihat dari nilai dampak nyata pertumbuhan yang memiliki nilai positif dimana sektor yang memberikan kontribusi terbesar adalah subsektor pertanian, peternakan, perburuan dan jasa pertanian dengan nilai kontribusi sebesar Rp 2648,26 juta atau Rp 2.648.260.000 kemudian disusul oleh kontribusi yang diberikan oleh subsektor kehutanan dan penebangan kayu denga nilai kontribusi sebesar Rp 1448,322 juta atau Rp 1.448.322.000 dan diikuti oleh subsektor perikanan dengan nilai kontribusi sebesar Rp 525,3186 juta atau Rp 525.318.600. Kemudian di bawah subsektor pertanian, peternakan, perburuan dan jasa pertanian sendiri yang memberikan kontribusi terbesar bagi pertumbuhan perekonomian Kabupaten Tambrauw adalah golongan tanaman hortikultura dengan nilai kontribusi sebesar Rp 2474,751 juta atau Rp 2.474.751.000 kemudian golongan peternakan yang menyumbang $\mathrm{Rp}$ 514,1205 juta atau Rp 514.120.500, diikuti dengan golongan tanaman perkebunan yang berkontribusi sebesar Rp 208,6171 juta atau Rp 208.617.100, dan golongan jasa pertanian dan perburuan dengan nilai kontribusi sebesar Rp 22,15327 juta atau Rp 22.153.270 sedangkan golongan tanaman pangan memberikan kontribusi negatif sebesar Rp 576,181 juta atau Rp $\quad 576.181 .000$ terhadap pertumbuhan perekonomian wilayah ini.

Pengaruh pertumbuhan ekonomi sektor dan subsektor pertanian, kehutanan dan perikanan Provinsi Papua Barat (Nij) terhadap pertumbuhan ekonomi sektor dan subsektor Kabupaten Tambrauw memberikan kontribusi positif sebesar Rp 10.563,38599 juta. Selanjutnya pengaruh bauran industri (Mij) perekonomian di Provinsi Papua Barat memberikan kontribusi negatif sebesar Rp 4187,690451 juta yang artinya bahwa pertumbuhan variabel regional sektor dan subsektor pertanian, kehutanan dan perikanan lebih kecil daripada pertumbuhan variabel regional total sektor di tingkat provinsi. Nilai negatif mencerminkan bahwa komposisi sektor dan subsektor pertanian, kehutanan dan perikanan cenderung mengarah kepada pertumbuhan yang lebih lambat terhadap perekonomian provinsi.

Selanjutnya, untuk nilai perhitungan keunggulan kompetitif diketahui bahwa walaupun nilai keunggulan kompetitif di setiap subsektor dan golongan pertanian, kehutanan dan perikanan mengalami kenaikan dengan nilai total positif sebesar Rp 889,6663578 juta rupiah. Jika dilihat lebih detail maka terlihat bahwa golongan tanaman pangan memiliki keunggulan kompetitif positif 84,36951764 juta rupiah kemudian golongan tanaman hortikultura dengan nilai keunggulan kompetitif sebesar Rp 814,1994761 juta serta subsektor kehutanan dan penebangan kayu dengan nilai keunggulan kompetitif sebesar Rp 2084.922385 juta. Dengan demikian maka bisa dikatakan bahwa wilayah Kabupaten Tambrauw memiliki daya saing yang lebih tinggi untuk hasil - hasil pertanian khususnya untuk golongan tanaman hortikultura dan tanaman pangan serta hasil - hasil dari subsektor kehutanan dan penebangan kayu.

\section{c. Penentuan Sektor Unggulan}

Berdasarkan perhitungan yang telah dilakukan dalam analisis Location Quotient (LQ) dan Shift Share, maka untuk mengambil kesimpulan sektor mana saja dalam kegiatan perekonomian wilayah Kabupaten Tambrauw yang menjadi sektor unggulan adalah yang memenuhi kriteria sektor basis dan memiliki keunggulan kompetitif (Cij) yang positif. Berdasarkan hasil analisis per subsektor maka yang memenuhi kriteria sebagai subsektor unggulan adalah golongan tanaman pangan, golongan tanaman hortikultura serta subsektor kehutanan dan penebangan kayu. Kedua golongan subsector pertanian, sektor ini memiliki nilai LQ $>1$ dan nilai keunggulan kompetitif yang positif.

Golongan tanaman pangan memiliki nilai rata rata LQ sebesar 2,327 (LQ > 1) dengan keunggulan kompetitif sebesar 84,36951764 juta rupiah kemudian golongan tanaman hortikultura dengan nilai rata - rata LQ sebesar 4,840 (LQ > 1) dan keunggulan kompetitif sebesar 814,1994761 juta rupiah atau Rp 814.199.476,1 dan diikuti oleh subsektor kehutanan dan penebangan kayu yang memiliki nilai rata - rata LQ sebesar 1,703 (LQ > 1) dengan nilai keunggulan kompetitif sebesar 2084,922385 juta rupiah atau $\mathrm{Rp}$ 2.084.922.385. Nilai positif dari komponen keunggulan kompetitif dari ketiga 
sektor ini menunjukkan bahwa ketiga sektor ini mempunyai daya saing yang tinggi di tingkat provinsi, sehingga pertumbuhannya di daerah lebih cepat daripada provinsi.

Analisis penentuan sektor unggulan diperlukan sebagai dasar untuk perumusan pola kebijakan pembangunan ekonomi Kabupaten Tambrauw di masa mendatang, sehingga kebijaksanaan pembangunan ekonomi dapat diarahkan untuk menggerakan sektor - sektor tersebut. Prioritas pembangunan ekonomi di wilayah Kabupaten Tambrauw haruslah didasarkan pada sektor unggulan, tidak hanya didasarkan pada sumber daya alam yang dimiliki, tetapi juga memperhatikan teknologi dan kualitas sumber daya manusia yang dimiliki, sehingga output yang dihasilkan akan mempunyai daya saing yang tinggi, karena didukung oleh potensi spesifik yang yang dimiliki daerah.

\section{KESIMPULAN DAN SARAN}

Berdasarkan hasil perhitungan dari analisis Location Quotient (LQ) dan analisis shift share menunjukkan bahwa yang menjadi subsektor unggulan di wilayah Kabupaten Tambrauw yang memenuhi kriteria sebagai sektor basis dan kompetitif atau memiliki daya saing yang tinggi di tingkat Provinsi Papua Barat adalah subsektor golongan tanaman pangan, subsektor golongan tanaman hortikultura dan subsektor kehutanan dan penebangan kayu. Sektor ekonomi Kabupaten Tambrauw selama 5 tahun terakhir yakni 2013 - 2017 masih bertumpu pada sektor primer yaitu sektor pertanian, kehutanan dan perikanan.

Sebagai rekomendasi, khususnya bagi Pemerintah Kabupaten Tambrauw dalam upaya meningkatkan pertumbuhan ekonomi agar lebih mengutamakan pengembangan subsektor unggulan yaitu subsektor golongan tanaman pangan, subsektor golongan tanaman hortikultura, dan subsektor kehutanan dan penebangan kayu. Sektor pertanian, kehutanan dan perikanan memiliki kontribusi yang tinggi terhadap pembentukan PDRB Kabupaten Tambrauw, sehingga perlu mendapatkan prioritas pengembangan dengan tidak mengabaikan sektor - sektor lainnya. Penelitian ini masih terbatas pada subsektor unggulan yang berada di bawah kategori pertanian, kehutanan dan perikanan alangkah lebih baiknnya apabila pada penelitian selanjutnya bisa dilakukan analisis sampai pada tahapan komoditi unggulan. Sehingga dapat memudahkan pemerintah dalam mengembangkan komoditas unggulan yang bisa cepat menggerakkan perekonomian wilayah Kabupaten Tambrauw.

\section{DAFTAR PUSTAKA}

Adisasmita, Rahardjo. 2014. Pertumbuhan Wilayah dan Wilayah Pertumbuhan. Yogyakarta : Graha Ilmu.

Badan Pusat Statistik. 2017. Produk Domestik Regional Bruto Kabupaten Tambrauw Menurut Lapangan Usaha 2013 - 2017. Badan Pusat Statistik Kabupaten Sorong.

Badan Pusat Statistik. 2018. Statistik Daerah Kabupaten Tambrauw 2018. Badan Pusat Statistik Kabupaten Sorong.

Badan Pusat Statistik. 2017. Produk Domestik Regional Bruto Provinsi Papua Barat Menurut Lapangan Usaha 2013 - 2017. Badan Pusat Statistik Provinsi Papua Barat.

Kurniawan, A., S. 2013. Analisis Struktur Perekonomian dan Pertumbuhan Ekonomi di Provinsi Banten Melalui Pendekatan LQ dan Shift Share. Jurusan Ekonomi Pembangunan Fakultas Ekonomi Universitas Negeri Semarang.

Rizani, Ahmad. Analisis Potensi Ekonomi di Sektor dan Subsektor Pertanian, Kehutanan dan Perikanan Kabupaten Jember. Jurnal Ekonomi Pembangunan Vol.15, No.2, Desember 2017.

Sari, S., R. Kontribusi Sektor Pertanian Dalam Struktur Ekonomi di Kabupaten Kaur Provinsi Bengkulu. Agrisep Vol.17 No.2 September 2018 Hal: 175 - 186.

Sun'an, M., Senuk, R. 2015. Ekonomi Pembangunan Daerah. Jakarta: Mitra Wacana Media.

Tarigan, Robinson, 2014. Ekonomi Regional Teori dan Aplikasi. Jakarta: PT Bumi Aksara.

Tumangkeng, Steeva. Analisis Potensi Ekonomi di Sektor dan Subsektor Pertanian, Kehutanan dan Perikanan Kota Tomohon. Jurnal Berkala Ilmiah Efisiensi Vol.18, No.01 (2018) https://ejournal.unsrat.ac.id/index.php/jb ie/article/view/20678/0 (diakses 4 September 2019). 